\title{
Doctors and the Dangers of Driving
}

\section{Citation}

Jones, David S. 2014. "Doctors and the Dangers of Driving." New England Journal of Medicine 370 (1) (January 2): 8-11. doi:10.1056/nejmp1311500.

\section{Published Version}

doi:10.1056/NEJMp1311500

\section{Permanent link}

http://nrs.harvard.edu/urn-3:HUL.InstRepos:34215108

\section{Terms of Use}

This article was downloaded from Harvard University's DASH repository, and is made available under the terms and conditions applicable to Open Access Policy Articles, as set forth at http:// nrs.harvard.edu/urn-3:HUL.InstRepos:dash.current.terms-of-use\#OAP

\section{Share Your Story}

The Harvard community has made this article openly available.

Please share how this access benefits you. Submit a story.

Accessibility 


\section{Doctors and the Dangers of Driving}

Writing in 1925 the editors of the Boston Medical and Surgical Journal warned that while civilization had brought progress, new technologies had introduced new causes of death and disability that had been "absent from life under a more primitive state of affairs." (1925-10/8) What prompted their concern? The automobile. Doctors had been quick to recognize the enjoyment that cars gave their drivers, as well as the efficiencies that cars offered doctors, many of whom still made house calls. But doctors also recognized driving's dire consequences. The editors wrote that "the automobile toll of the streets is appalling." Nearly $30 \%$ of the deaths were of children, "a massacre of the innocent." Doctors have now worked for over a century to characterize the dangers of driving. They have remained ambivalent, however, about taking more aggressive action to combat the epidemic.

Automobile accidents claimed their first victim in the United States in 1899. Mortality rose steeply in the early twentieth century. By 1912 the coroner's clerk in New York City warned that "'Our streets are becoming as perilous as a battlefield.'" (1912-9/19) The deaths were but one of many concerns. Automobiles first appeared in this Journal in 1904 in a report about a characteristic fracture seen in car owners. Early cars utilized a hand crank ignition that could backfire and fracture a careless driver's distal radius. (1904) By 1912 cars had been implicated in the burgeoning epidemic of obesity: "Persons of extremely indolent habits of life may be found who rarely walk more than the few steps that are needed from the 
chamber to the elevator, from the elevator to the dining-room, or lounging-room, and then to the automobile." (1912-12/5) Carbon monoxide exhaust built up to dangerous levels in tunnels and garages. $(1922,1928)$ Automotive air conditioners exposed drivers to new reservoirs of respiratory allergens. (1984) Car mechanics suffered from asbestosis (1961) and lead poisoning (1987-7/23). Even hospitals were at risk. Administrators complained in 1934 about the financial burden of providing uncompensated care to accident victims. (1934)

As infectious disease mortality fell, rising automotive mortality demanded increasing attention from doctors. Researchers from the Harvard School of Public Health published a major report, "Human Factors in Highway Safety," in 1957. Describing accident mortality as a "mass disease of epidemic proportions," they made an explicit analogy to infectious diseases. Just as doctors had led campaigns against infections, their "responsibility to achieve control over accidental trauma is now becoming apparent." (1957-4/25) Only doctors had the expertise in human biology and behavior needed "to contribute to the prevention of highway accidents, particularly through the development of adequate physical standards for the licensing of drivers, the determination of the role of various pathologic processes and physical conditions in causing accidents and the indoctrination of the public regarding the psychologic, physiologic and medical factors influencing the safety of driving." (1957-5/9) As Boston's Medical Examiner argued ten years later, "It is time for automobile fatalities and injuries to be viewed much as a 
pathologic entity with a recognizable etiology and predictable sequelae and subject to preventive measures." (1967)

When doctors studied the etiology of motor vehicle accidents, they faced two interesting challenges. First, they had to decide how much attention to devote to alcohol or to other causes of impaired driving. The dangers of drunk driving had been recognized in the early 1900s. Doctors knew that it was the single largest cause of automotive mortality. (2011) But doctors often looked elsewhere. A 1965 California study found that diabetes, epilepsy, cardiovascular disease, mental illness, and illicit drug use also increased accident rates. (1965-12/23) Subsequent studies focused on sleep apnea (1989, 1999), epilepsy and diabetes (1991), marijuana and cocaine (1994), cell phones (1997-2/13a), drowsy driving (19979/11), and ventricular tachycardia (2001). Some doctors critiqued their colleagues for being "relatively silent about the relation between alcohol and motor vehicle accidents." (1987-11/12) Doctors defended their other interests, arguing in 2001 that "accidents are potentially preventable by the restriction of the driving privileges of persons at high risk for such illnesses." (2001) This argument, of course, applies equally well to alcohol. There must be other factors at work that directed physician attention away from alcohol to the less common causes of automotive mortality.

Second, doctors recognized that some accidents were iatrogenic. Sedatives and other drugs compromised driver performance. Concerns first appeared with insulin and the risk that a diabetic driver might lapse into a hypoglycemic coma. 
(1957) New drugs brought new fears, from benzodiazepines in the 1960s to zolpidem and other soporifics today. (2013-8/7) The profession watched carefully as courts struggled to determine if physicians would be held liable when they prescribed sedating medications to patients who continued to drive. (2008)

Doctors did not simply study the etiology of car crashes. Many wanted to contribute to the solution. The 1957 report on "human factors" showed that 80 to $90 \%$ of accidents could be traced to driver error. (1957-4/25) But the authors did not think that interventions should focus solely on drivers. As has so often happened at the interface between medicine and morality, they supported a pragmatic approach. Accidents reflected an interaction between the driver, the car, and the road. Suspecting that driver error would never be eliminated, physicians worked to minimize the consequences of the accidents that would inevitably occur. This could be done through a "thorough reconstruction of streets and roads," (1925-10/8) or through efforts to redesign car interiors with insights from biomechanics to optimize comfort and safety. (1957-5/2)

While doctors were comfortable studying epidemiology and advocating certain reforms, they were less enthusiastic about reporting potentially dangerous drivers. A 1924 proposal called for careful scrutiny of drivers, and physicians knew well that "mental and physical defects" should bar some people from driving. The editors of the Journal were wary, but supportive: "Multiplicity of laws and regulations are deplorable, but humanity and economics will require of all, yielding to inevitable restrictions." (1924). When the Massachusetts legislature 
considered requiring doctors to certify drivers' vision, the editors again were cautious. Doctors "would want all unnecessary red tape done away with but where human life is at stake physicians have been willing to meet even unpleasant regulations." (1925-8/13) In 1965 the editors expressed renewed concern about proposals for the medical regulation of "unsafe drivers." They worried that "Such a law, no matter how noble in intent, places a practical and philosophic onus on the physician." (1965-1/7) Patients might avoid doctors. Many would continue to drive even if their licenses were revoked. Follow up studies have indeed shown that while medical warnings decrease accident rates in medically high-risk drivers, they are associated with increased depression and reduced follow-up. (2012)

One of the most important challenges for doctors today is determining when the evidence base is strong enough to justify strong actions. When this Journal published its first report on cell phones and distracted driving in 1997, the authors did not recommend a ban on cell phone use. They placed the burden instead on drivers: the "role of regulation is controversial, but the role of individual responsibility is clear." (1997-2/13a) The accompanying editorial agreed that "laws banning all telephone use while driving would be premature without better data." (1997-2/13b) All technology-laden democratic societies struggle with the relationship between evidence and regulation. Should governments set limits only once risk is proven beyond a reasonable doubt? Should a precautionary principle allow regulation in anticipation of likely risk? Even clear evidence can be set aside. In 1987 William Foege condemned the decision to raise the speed limit to $65 \mathrm{mph}$ : 
"It is not only a failure of Congress to obtain and use the appropriate facts but also a failure of the health professions to convey their knowledge to policy makers." (1987-5/28) It remains to be seen whether emerging data about cell phones and driving will motivate lawmakers to respond.

Despite the reticence of doctors and legislators to act decisively, progress has been made. Fatalities per mile driven have fallen $80 \%$ since 1950. (2013-5/23) This success reflects a broad public health approach: not just moral outrage against drunk, drowsy, or distracted drivers, but also technological fixes and public education. (2011) Much more progress could be made. How often do doctors discuss the risk of distracted driving with their patients? (2010) Shouldn't doctors work to restrict the driving privileges of any patient who drinks to intoxication, and not just those with impaired vision or uncontrolled seizures? There will always be room for further research about the dangers of driving. But there is also need for physicians to implement appropriate responses when the evidence is good enough. 


\section{Boston Medical and Surgical Journal}

1904. Lund FB. Fractures of the radius in starting automobiles. 151:481-3. (11/03)

1912. Increase of vehicular mortality. 167:411. (9/19)

1912. The automobile knee. 167:816-7. (12/5)

1922. Henderson Y. Automobile exhaust gas as a health hazard. 187:180-3. (8/3)

1924. Automobile accidents. 190:725. (4/24)

1925. A circular letter objecting to the examination of motor car drivers. 193:323. $(8 / 13)$

1925. Automobile accidents in the United States. 193:697-8. (10/08)

\section{New England Journal of Medicine}

1928. Health hazard from automobile gas. 198: 647-8. (5/10)

1934. The burden on hospitals imposed by automobile accidents. 210:109. (1/11)

1957. Lister J. The diabetic driver. 256:610. (3/28)

1957. McFarland RA, Moore RC. Human factors in highway safety: a review and evaluation. 256:792-9. (4/25)

1957. McFarland RA, Moore RC. Human factors in highway safety: a review and evaluation. 256:837-45. (5/2)

1957. McFarland RA, Moore RC. Human factors in highway safety: a review and evaluation. 256:890-7. (5/9)

1961. Brugsch HG, Bavley $\mathrm{H}$. Asbestosis in a worker engaged in automobile undercoating. 265:379-81. (8/24)

1965. The unsafe driver. 272:47-8. (1/7)

1965. Waller JA. Chronic medical conditions and traffic safety. 273:1413-20. $(12 / 23)$

1967. Luongo MA. Death in the automobile. 276:798-9. (4/6)

1984. Kumar P, Marier R, Leech SH. Respiratory allergies related to automobile air conditioners. 311:1619-21. (12/20)

1987. Foege WH. Highway violence and public safety. 316:1407-8. (5/28)

1987. Goldman RH, Baker EL, Hannan M, Kamerow DB. Lead poisoning in automobile radiator mechanics. 317:214-8. (7/23)

1987. Colquitt M, Fielding P, Cronan JF. Drunk drivers and medical and social injury. 317:1262-6. (11/12)

1989. Findley LJ, Fabrizio M, Thommi G, Suratt PM. Severity of sleep apnea and automobile crashes. 320:868-9. (3/30)

1991. Hansotia P, Broste SK. The effect of epilepsy or diabetes mellitus on the risk of automobile accidents. 324:22-6. (1/3)

1994. Brookoff D, Cook CS, Williams C, Mann CS. Testing reckless drivers for cocaine and marijuana. 331:518-22. (8/25)

1997. Redelmeier DA, Tibshirani RJ. Association between cellular-telephone calls and motor vehicle collisions. 336:453-8. (2/13a) 
1997. Maclure M, Mittleman MA. Cautious about care telephones and collisions. 336:501-2. (2/13b)

1997. Mitler MM, Miller JC, Lipsitz JJ, Walsh JK, Wylie D. The Sleep of long-haul truck drivers. 337:755-61. (9/11)

1999. Teran-Santos J, Jimenez-Gomez A, Cordero-Guevara J. The association between sleep apnea and the risk of traffic accidents. 340:847-51. (3/18)

2001. Akiyama T, Powell JL, Mitchell LB, Ehlert FA, Baessler C. Resumption of driving after life-threatening ventricular tachyarrhythmia. 345:391-7. (8/9)

2008. Annas G). Doctors, drugs, and driving -- tort liability for patient-caused accidents. 359: 521-5. (7/31)

2010. Ship AN. The most primary of care -- talking about driving and distraction. 362:2145-7. (6/10)

2011. Lerner BH. Drunk driving, distracted driving, moralism, and public health. 365:879-81. (9/8)

2012. Redelmeier DA, Yarnell CJ, Thiruchelvam D, Tibshirani RJ. Physicians' warning for unfit drivers and the risk of trauma from road crashes. 367:1228-36. (9/27)

2013. Hemenway D, Miller M. Public health approach to the prevention of gun violence. 368: 2033-5. (5/23)

2013. Farkas RH, Unger EF, Temple R. Zolipdem and driving impairment -identifying persons at risk. 369:689-91. (8/7) 